\title{
RFLP-based Analysis of Recombination among Resistance Genes to Fusarium Wilt Races 1, 2, and 3 in Tomato
}

\author{
J.W. Scott, H.A. Agrama, and J.P. Jones \\ Gulf Coast Research and Education Center, University of Florida, 5007 60th Street East, Bradenton, \\ FL 34203-9324
}

AdDITIONAL INDEX WORDS. disease resistance, Fusarium oxysporum f. sp. lycopersici, linkage, Lycopersicon esculentum

\begin{abstract}
Tomato (Lycopersicon esculentum) line E427 has resistance genes to all three races of F usarium oxysporum f.sp. lycopersici derived from $L$. pennellii accession LA 716 and $L$. pimpinellifolium accession PI 126915. To determine genes that confer resistance to specific races of fusarium wilt, line $\mathbf{E} 427$ was crossed to susceptible 'Bonny Best' and then $F_{2}$ and backcross (to 'Bonny Best') seed were obtained. Self-pollinations resulted in 337 lines and progeny of each line was inoculated separately with fusarium wilt races 1, 2, or 3. Plants from lines whose segregation suggested recombination of resistance were self-pollinated and reinoculated until disease reactions were homozygous. Four lines were obtained with resistance to both races 2 and 3 , but susceptible to race 1 . These lines had the $L$. pennellii alleles at restriction fragment length polymorphism (RFLP) markers linked to $I$-3 on chromosome 7 and lacked $L$. pimpinellifolium alleles linked to $I$ and I-2 on chromosome 11. Complementation $\left(F_{2}\right)$ data indicated race 2 resistance on chromosome 7 was controlled by a single dominant gene. Three lines were resistant to race 2, but susceptible to races 1 and 3 . These lines had L. pimpinellifolium alleles at TG105 and flanking markers encompassing a $14.4 \mathrm{cM}$ region indicating the presence of $I-2$, and no $L$. pennellii alleles at markers linked to $I-3$. Three lines were resistant to race 1 , but susceptible to races 2 and 3 . All three lines had $L$. pimpinellifolium alleles at TG523 confirming linkage to $I$ on chromosome 11 and no $L$. pennellii alleles at markers tightly linked to I-3. However, one of the lines, 415 , had $L$. pennellii alleles at CT113 on chromosome 7. This data along with $\mathrm{F}_{2}$ complementation data suggests the possible existence of a second race 1 resistant locus, $I 1$, in this region. The four lines resistant to both races 2 and 3 were backcrossed again to 'Bonny Best' and self-pollinated progeny from 174 plants were screened as described above. Two lines derived from different $\mathrm{BC}_{1} \mathrm{~S}_{1}$ lines that were fusarium wilt race 3 resistant and susceptible to race 1 had intermediate resistance to race 2 . These two lines did not have the $L$. pennellii alleles at TG183, TG174, and CT43 near the I-3 locus indicating crossovers in this region resulted in reduced race 2 resistance. Collectively, this is the first clear break in the fusarium wilt race 2 and race 1 resistance linkage on chromosome 11. It appears that the race 1 resistance derived from PI 126915 is controlled by the $I$ gene. On chromosome 7, there was a break between the $I-3$ and $I I$ genes indicating I-3 does not confer race 1 resistance. The crossovers resulting in reduced resistance to race 2 could be within a complex $I-3$ locus or a tightly linked race 2 locus.
\end{abstract}

The host-pathogen interaction of tomato (Lycopersicon esculentum Mill.) and Fusarium oxysporum Schlecht. f.sp. lycopersici (Sacc.) Snyder \& Hansen has been widely studied. Several major dominant resistance genes and the races they control have been identified. The first vertical gene for resistance $(I)$ was reported by Bohn and Tucker(1939) in L. pimpinellifolium accession PI 79532. This gene was later assigned to chromosome 11 (Paddock, 1950). Recently $I$ was found to be linked to chromosome 11 restriction fragment-length polymorphism (RFLP), TG523 (P. Lindhout, personal communication). This position is consistent with the location reported for RFLP introgression lines at the Solgenes website (http://grain.jouy.inra.fr/cgi-bin/webace/webace?db=solgenes). A second race was discovered before 1940 (Alexander and Tucker, 1945) but was not reported again until 1961 when the pathogen caused serious crop losses in Florida (Stall and Walter, 1965). A gene $(I-2)$ for resistance to the second race was discovered in a L. pimpinellifolium-L. esculentum $\mathrm{F}_{1}$ accession, PI 126915 (Stall and Walter, 1965). The I-2 gene was mapped to chromosome 11 by morphological markers (Laterrot, 1976) and by RFLP marker TG105 (Sarfatti et al., 1989; Segal et al., 1992). Simons et al. (1998) cloned $I-2$ and it is a complex locus (Ori et al., 1997; Simons et al., 1998). Stall and Walter (1965) originally reported PI 126915 was also resistant to race 1 , but it was not clear if this was due to $I-2$ or to a linked gene, either $I$ or another gene. Cirulli and Alex-

Received for publication 9 June 2003. Accepted for publication 18 Nov. 2003. Florida Agricultural Experiment Station journal series R-08534. We thank John Petti, Karon Pearce, and Russell Owens for technical assistance. ander (1966) reported that resistances to race 1 and race 2 from PI 126915 were controlled by separate genes but did not confirm $I$ to be the race 1 resistance gene. Later, Laterrot and Philouze (1984) reported recombination between genes for resistance to race 2 ( $I$ 2 ) and race 1 . They obtained a line, which was resistant only to race 2, although this line was less susceptible to race 1 than the susceptible control line. Laterrot and Philouze (1984) concluded that the $I-2$ gene gave a reduced susceptibility to race 1 . It still is not known if the race 1 resistant gene linked to I-2 from PI 126915 is $I$ or another gene.

Meanwhile, a third race of fusarium wilt was discovered in Australia (Grattidge and O'Brien, 1982) and now spread to the southeastern and western United States, Mexico and Japan. Resistance to race 3 ( $I-3$ gene) was discovered in L. pennellii (McGrath et al., 1987; Scott and Jones, 1989). In fact, all accessions of $L$. pennellii carry resistance to all three races of the fusarium wilt organism (Scott and Jones, 1990). Bournival et al. (1989) determined the $I-3$ gene from LA 716 was linked to an allozyme of Got-2 on chromosome 7. This marker could also be used to select for race 1 and 2 resistance derived from LA 716 (Bournival et al., 1990). From this work, it was not clear whether the resistances to races 1 and 2 were conferred by $I-3$ or genes linked to $I-3$. Later, Tanksley et al. (1992) reported I-3 was linked to RFLP markers TG128, TG217, and TG 170. Sarfatti et al.(1991) reported a gene (II) conferring resistance to race 1 derived from LA 716, was linked between RFLP markers TG20 and TG128 on chromosome 7. They reported this gene not to be an allele of $I-3$ presumably due to differences in linkage estimates from Got-2. Resistance to 
race 3 was not evaluated in their experiments. Later Sela-Buurlage et al. (2001) stated that the $I-3$ gene confers resistance to all three races. Thus, there is some confusion as to the genetic control of fusarium wilt resistance on chromosome 7.

RFLPs have been used to generate tomato molecular linkage maps (Fulton et al., 1997; Haanstra et al., 1999; Ron et al., 2000; Tanksley et al., 1992). However, RFLPs have also been used to identify markers that are closely linked to tomato disease resistance genes (Grube et al., 2000; Lindhout 1995; Martin et al., 1993) such as tobacco mosaic virus (Young et al., 1988), powdery mildew (Chunwongse et al., 1994), yellow leaf curl virus (Zamir et al., 1994), corky root rot (Doganlar et al., 1998), root-knot nematode (Kaloshian et al., 1998), and cucumber mosaic virus (Stamova and Chetelat, 2000).

In this work, we use fusarium wilt inoculations to develop and identify lines that have crossovers between resistance genes on chromosome 7 or chromosome 11. Complementation tests $\left(\mathrm{F}_{2}\right)$ and RFLP analyses were used to identify genes present and determine their approximate locations. On chromosome 11 the goal was to determine if the race 1 resistance gene linked to $I-2$ is the $I$ gene and to see if $I-2$ affected race 1 resistance. On chromosome 7 the goal was to determine if genes other than $I$ - 3 confer race 1 or race 2 resistance and determine approximate map locations for these genes.

\section{Materials and Methods}

ReCOMbINANT LINE DEVELOPMENT. Lycopersicon pennellii accession LA 716, resistant to all three races of the fusarium wilt pathogen was crossed with a breeding line carrying the $I$ - 2 gene and an unknown linked race 1 resistance gene on chromosome 11. The $F_{1}$ was selected for race 3 resistance and backcrossed to another $I-2$, race 1 resistant breeding line. After further selection for race 3 resistance, a homozygous resistant $\mathrm{F}_{3}$ line designated E427 was derived that was also resistant to races 1 and 2 (Scott and Jones, 1989). Line E427 has the $I-3$ gene on chromosome 7 that confers race 3 resistance, while resistance to races 1 and 2 could be due to resistance genes on chromosome 11 and/or chromosome 7 (Bournival et al., 1990). In 1986, E427 was crossed with 'Bonny Best' (BB), which is susceptible to all 3 races of the fusarium wilt pathogen. The $\mathrm{F}_{1}$ was self-pollinated $\left(\mathrm{F}_{2}\right)$ and backcrossed to $\mathrm{BB}$ $\left(\mathrm{BC}_{1}\right)$. Self-pollinated seed were saved from $187 \mathrm{BC}_{1}$ plants and $150 \mathrm{~F}_{2}$ plants. Seedlings from each $\mathrm{BC}_{1}$ and $\mathrm{F}_{2}$ were divided into three groups and inoculated with race 1, 2, or 3 of the fusarium wilt pathogen. Resistant plants from lines whose segregation ratios indicated crossing-over between resistance genes were planted in the field where self-pollinated seed was saved from several plants per line. Progeny were inoculated separately for all three races, and this procedure was repeated again until homozygosity for the disease reactions was obtained. $\mathrm{BC}_{1} \mathrm{~S}_{1}$ and $\mathrm{F}_{3}$ lines carrying resistance to races 1 and 2 but not to race 3 were somewhat common but ignored due to the difficulty in distinguishing if these had crossovers on chromosome 7 or were lines carrying only $I-2$ and linked race 1 resistance on chromosome 11. Data are presented from the $\mathrm{BC}_{1} \mathrm{~S}_{3}$ and $\mathrm{F}_{5}$ generations. Several plants of each Fusarium recombinant line $\left(\mathrm{BC}_{1} \mathrm{~S}_{3}\right.$ and $\left.\mathrm{F}_{5}\right)$, were tested for Got-2 using starch gel electrophoresis as described by Bournival et al. (1989) and Vallejos (1983).

Four lines were obtained that were resistant to races 2 and 3 but susceptible to race 1. In Fall 1994, these four lines were crossed to BB and backcrosses were made to BB in Spring 1995. In Spring 1998, the backcrosses were grown in the field and self-pollinated seed $\left(\mathrm{BC}_{1} \mathrm{~S}_{1}\right)$ was saved from 174 plants. In Spring $1999, \mathrm{BC}_{1} \mathrm{~S}_{1}$ progeny were divided into three groups and each was inoculated with race 1,2 , or 3 of the fusarium wilt pathogen. When segregation ratios indicated crossing-over between resistance genes, resistant plants were transplanted to the field and self-pollinated seed was saved from several plants per line. This process was repeated until homozygous lines were obtained. Pooled data from the $\mathrm{BC}_{1} \mathrm{~S}_{3}$ to $\mathrm{BC}_{1} \mathrm{~S}_{5}$ generations in 2000 and 2001 are presented for two lines (732 and 751), which were clearly resistant only to race 3.

Complementation TeSTS. Since dominant genes conferred resistance, $\mathrm{F}_{2}$ complementation tests were conducted to determine allelism of recombinant lines. Three lines resistant to race 1 but susceptible to races 2 and 3 were crossed to 'Manapal' $(I)$ and the $F_{1}$ was later self-pollinated to produce $F_{2}$ seed. The three race 1 resistant parent lines $\left(415,392\right.$, and 399), the $\mathrm{F}_{2}$ 's, 'Manapal', and BB $\left(I^{+} I^{+}\right.$, susceptible control) were inoculated with race 1 . A two gene model ( 15 resistant : 1 susceptible in the $\mathrm{F}_{2}$ ) was then tested for goodness of fit by Chi-square. Two lines resistant to races 2 and 3 but not race 1 were crossed with Fla. $7182,(I-2)$. The resultant $F_{1}$ was self-pollinated to obtain $\mathrm{F}_{2}$ seed. The two race 2 and 3 resistant parent lines (218 and 256), Fla. 7182, the $\mathrm{F}_{2}$ 's, and 'Manapal' ( $I$, $I-2+I-2+$ susceptible control) were screened for race 2 resistance and tested for fit to a two gene model as above.

INOCULATION. The race 1 isolate, 626, was originally sent from Cirulli (Cirulli and Alexander, 1966). The race 2 and race 3 isolates, 548 and 5397, respectively, were originally from Florida farms. These three isolates were grown on potato dextrose agar at $28^{\circ} \mathrm{C}$ for 1 week and comminuted in a blender with $\mathrm{dH}_{2} \mathrm{O}$ and adjusted to $6 \times 10^{7}$ spores $/ \mathrm{mL}$. Seedlings at the cotyledon stage were root dipped in the slurry and transplanted to Todd planter flats containing 128 cells $\left(3.8 \mathrm{~cm}^{3}\right)$. The cells contained a 1:1 (by volume) ratio of peat and vermiculite amended with dolomite, superphosphate, and hydrated lime so the $\mathrm{pH}$ was 6.5. Supplemental liquid fertilizer was applied to maintain plant growth. Plants were scored several times over a 30 day period for disease symptoms which ranged from death to stunting, wilting, yellowing of the foliage, epinasty, and/or enlarged stems. Healthy plants had none of the above symptoms and retained their green cotyledons. Stems of questionable plants were cut longitudinally and rated as diseased if they had vascular browning. Several inoculations were done from 1990 to 2001 in greenhouses under ambient conditions. Spring temperatures ranged from 22 to $30^{\circ} \mathrm{C} \mathrm{d} / 12$ to $18^{\circ} \mathrm{C} \mathrm{n}$ (typically $27^{\circ} \mathrm{C} \mathrm{d} / 18^{\circ} \mathrm{C}$ n). Summer or fall temperatures ranged from 30 to $33{ }^{\circ} \mathrm{C} \mathrm{d} / 21$ to $25^{\circ} \mathrm{C} \mathrm{n}$. The recombinant lines with resistance to only race 1 , race 2 , or both races 2 and 3 and controls were inoculated over several experiments (generally three) and data were pooled over these experiments for clarity of presentation. Plant numbers tested per line for each race ranged from 98 to 329. The lines resistant to race 3 alone were tested in three later experiments and data were also pooled. Plant numbers tested per line for each race ranged from 147 to 176 . The following control lines were used for race 1 inoculations (BB-susceptible, 'Manapal'-resistant); race 2 inoculations ('Manapal'-susceptible, Fla. 7182 or 'Horizon'-resistant); and race 3 inoculations (Fla. 7182 or 'Horizon'-susceptible, I3R1 or Fla. 7547-resistant).

RFLP ANALYSES. The RFLPscreening method we used was similar to stepped aligned inbred recombinant strains (STAIRS) approach that is generally applicable yet focused on precise QTL location. It allows one to "zoom in" on genes responsible to almost any degree of accuracy and because only few lines are required at any one time, it permits very large-scale replication to enhance the statistical power of both trait and gene-expression analysis (Kearsey, 2002).

Total tomato DNA was extracted from fresh leaf tissue of 
pooled 15 to 20 seedlings following the method of Burbidge et al. (1995). Genomic DNA of each line was digested with the restriction enzymes EcoRI, HindIII, BamHI or XbaI. Digested DNA was fractioned in $1.0 \%$ agarose gels. After electrophoresis, gels were denatured, neutralized and Southern blotted onto uncharged nylon membrane using standard techniques. DNA probes were labeled by PCR amplification with $2.5 \%$ digoxigenin d-UTP (BoehringerMannheim, Ridgefield,Conn.). The probes were detected according to chemiluminescent protocol described by Agrama and Moussa (1996) and Bohorova et al. (1999). RFLP probes were obtained from S.D. Tanksley's Laboratory, Cornell University, New York. These probes spanned chromosomes 7 and 11 with some concentration near reported fusarium wilt resistance loci.

\section{Results and Discussion}

Phenotypic analysis. We identified 12 lines in the E427 populations that separate resistance specificities attributed to $I$, I-2, and I-3. Analysis of these lines using a STAIRS approach to provide a focused analysis of the loci responsible for the resistant phenotypes, demonstrate that the $I-3$ locus on chromosome 7 does not provide resistance to all three races of fusarium wilt. The results of STAIRS analysis are consistent with the existence of a second gene, Il (Sarfatti et al., 1991), conferring resistance to race 1 . Furthermore, a region tightly linked to I-3 appears to confer race 2 resistance. On chromosome 11 we demonstrate that the $I-2$ locus has no effect on race 1 resistance and that $I$ is in fact the gene conferring race 1 resistance that was introgressed with the $I-2$ gene. The recombinant lines developed in the course of this work will provide the basis to rigorously test hypotheses about the specificity of Fusarium resistance genes using a more diverse array of pathogen isolates and about the existence of loci that might confer partial resistance.

Fusarium wilt race recombinant lines from the E427 popula- tions included three resistant to race 1 alone, three resistant to race 2 alone, and four resistant to both races 2 and 3 (Fig. 1). All lines trace back to separate $\mathrm{BC}_{1}$ plants except 415 , which was derived from an $\mathrm{F}_{2}$ plant. All lines had some healthy plants to races they were susceptible to, and often these frequencies were higher than those of $\mathrm{BB}$. For instance, for race 1 inoculation there were between $11 \%$ and $16 \%$ healthy plants for lines resistant to race 2 alone and races 2 and 3 alone, whereas BB had $<2 \%$ healthy. The increased frequency of healthy race 1 inoculated plants could be due to an effect of the race 2 and/or race 3 resistance genes, modifier genes, or both. However, these results should not be confused with those reported by Laterrot and Philouze (1984) who found less susceptibility to race 1 in 'Ideucenzi', their race 2 resistant line. We had previously tested 'Ideucenzi' and confirmed their results (J.W. Scott and J.P. Jones, unpublished data). The present lines were much more susceptible to race 1 than 'Ideucenzi' although a direct comparison was not made in these experiments.

Two lines, 732 and 751, with clear resistance only to race 3 were eventually obtained from the $174 \mathrm{BC}_{1} \mathrm{~S}_{1}$ lines that were screened for all three races (Fig. 2). Lines 732 and 751 came from crosses of BB with lines 218 and 383, respectively, which were resistant to both races 2 and 3 (Fig. 1). Both lines were highly susceptible to race 1 , but had an intermediate race 2 disease incidence that varied between seasons ( $11 \%$ to $49 \%$ and $13 \%$ to $76 \%$ healthy plants for 732 and 751 , respectively). However, the healthy race 2 inoculated plants were stunted compared to race 3 inoculated plants (Fig. 3). The race 2 reactions for these lines, was similar to that of 'Ideucenzi' for race 1 (Laterrot and Philouze, 1984; Scott and Jones, unpublished). This intermediate race 2 susceptibility could be due to an effect of $I-3$ on race 2 or perhaps the crossover location, which could be within a complex resistance locus that could either be $I-3$ or a tightly linked race 2 resistance locus. In these experiments, there were inexplicably lower percentages of

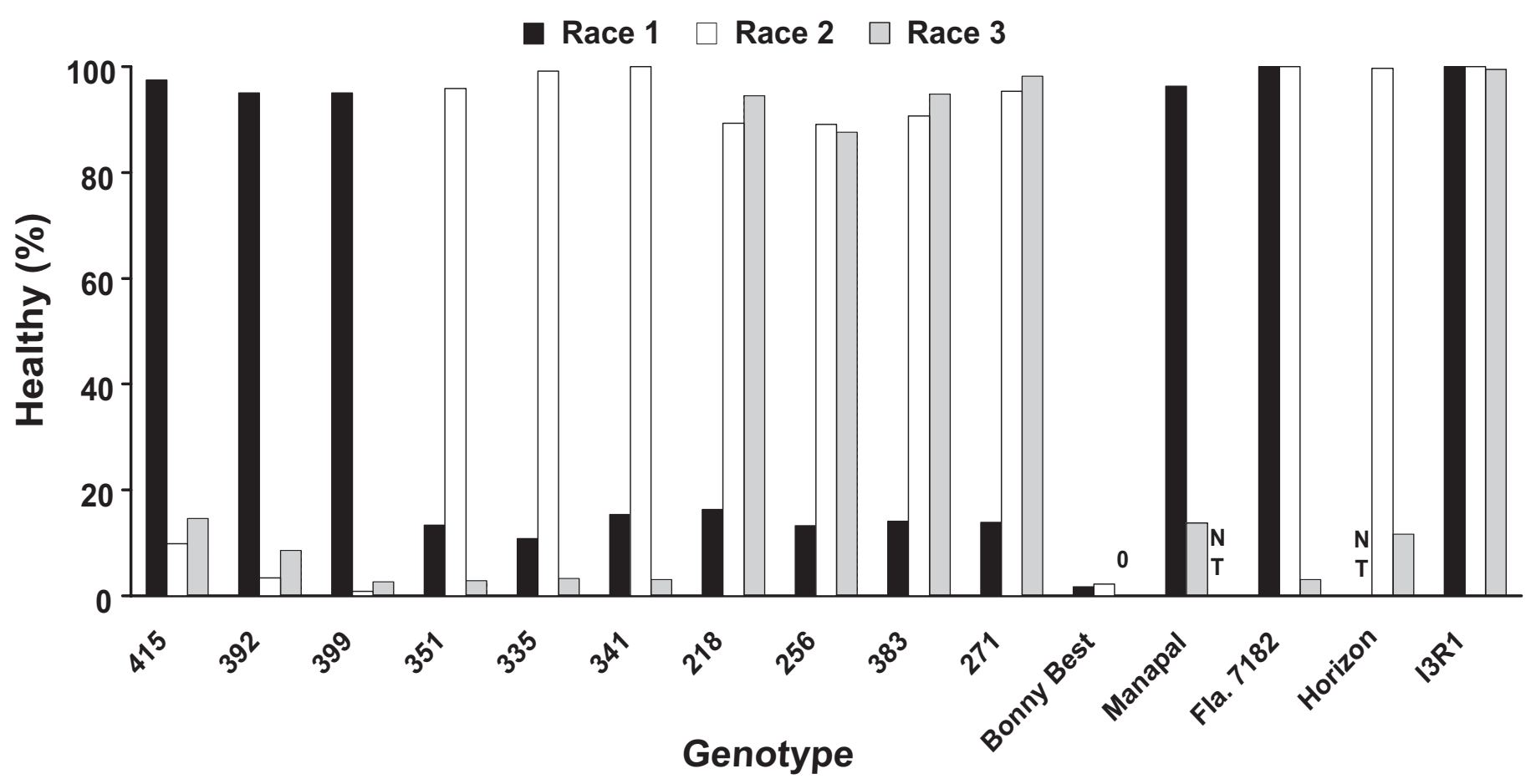

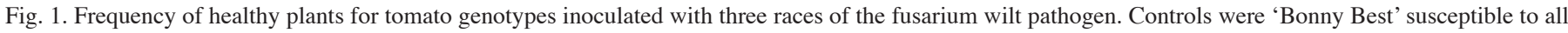

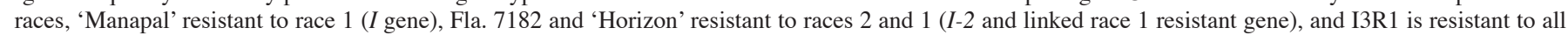
three races. $I-3, I-2$, and race 1 resistant gene). NT $=$ not tested, $0=0 \%$ healthy. 


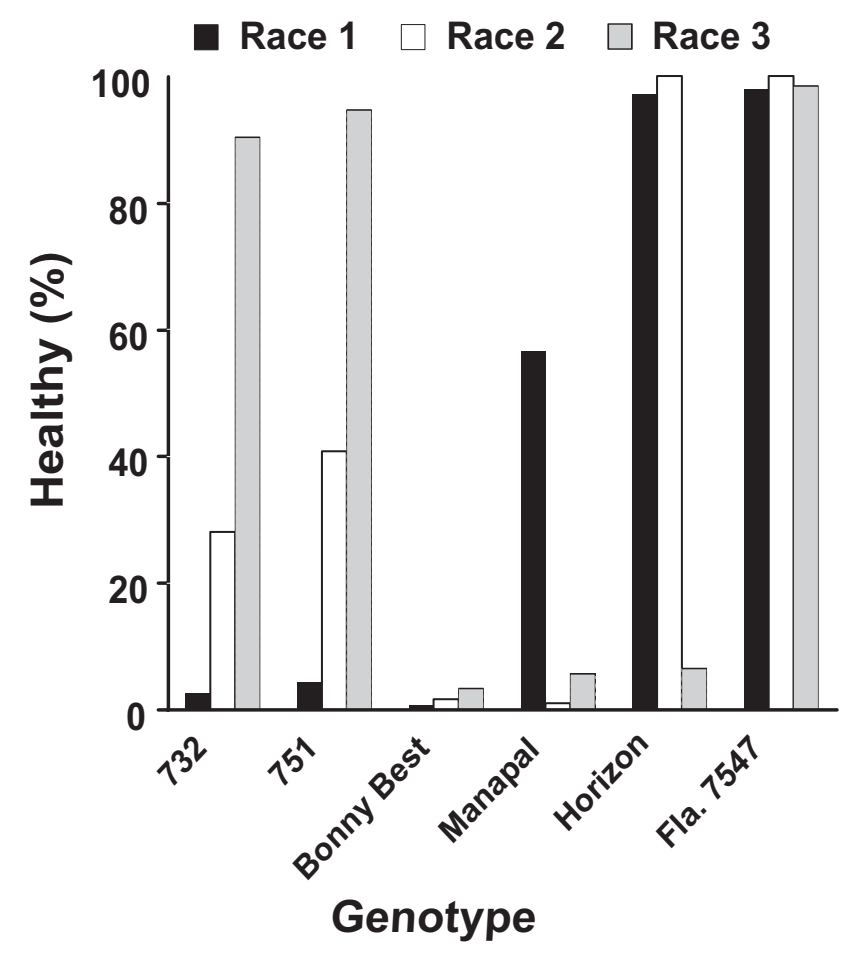

Fig. 2. Frequency of healthy plants for tomato genotypes inoculated with three races of the fusarium wilt pathogen. Controls are 'Bonny Best' susceptible to all races, 'Manapal' resistant to race 1 (I-gene), 'Horizon' resistant to races 2 and 1 ( $I-2$ and linked race 1 resistant gene) and Fla. 7547 resistant to all three races $(I-3, I-2$, and race 1 resistant genes).

healthy race 1 inoculated plants in 'Manapal' as compared to the previous experiments (Figs. 1 and 2).

Complementation tests. Complementation tests of the $\mathrm{F}_{2}$ generations from two race 1 resistant lines, 392 and 415, with 'Manapal' (I) indicated that both possess the $I$ gene since the digenic 15:1 ratio was rejected due to a deficiency of diseased plants (Table 1 ). It has long been surmised that $I$ was linked to $I-2$ on chromosome 11 and these tests provide evidence that this is the case. The $F_{2}$ generation from the cross of 'Manapal' with line 399 had an unacceptable fit to a two gene model due to an excess of susceptible plants suggesting 399 does not have $I$, but has a resistant gene on chromosome 7 (Table 1). However, all three race 1 resistant lines have the TG523 allele linked to $I$ (Lindhout, personal communication, Fig. 4). Lines 392 and 399 had no chromosome 7 L. pennellii RFLP markers indicating these lines only have the I gene (Fig. 5). It is not known why the $\mathrm{F}_{2}$ progeny derived from line 399 had such a high percentage of susceptible plants especially relative to the two parent lines. Incomplete penetrance of $I$ has been reported by Alon et al. (1974) and possibly heterozygotes in this particular cross had less penetrance. Collectively, data for lines with and without race 1 resistance suggest the location of $I$ is in the region of TG523 and TG508 that is $2.7 \mathrm{cM}$ away (Fig. 4). However, information on race 1 resistance for the introgression lines reported at the Solgenes website (http://grain.jouy.inra.fr/cgi-bin/webace/ webace? $\mathrm{db}=$ solgenes) indicate $I$ is not in $\mathrm{I} 211-1$ a line with the TG508 marker. Thus, from Solgenes information and our data $I$ is likely near TG523 and between it and TG7.

However, there was evidence that a race 1 resistant gene (II) on chromosome 7 was present in 415 . There was a very low percentage $(0.8)$ of race 1 susceptible plants in the $415 \mathrm{x}$ 'Manapal' $\mathrm{F}_{2}$ while 'Manapal' had 3.3\% susceptible plants (Table 1). If 415 had both $I$ and $I I$, then it would be expected that one-fourth of the $\mathrm{F}_{2}(246$ plants) would be $I I / I I^{+} I I^{+}$. If there was $3.3 \%$ escapes in those 246 $I I / I 1^{+} I I^{+} \mathrm{F}_{2}$ plants, the expected number of susceptible $\mathrm{F}_{2}$ plants would be 8.1 and there were in fact eight susceptible plants (Table 1). Also, line 415 had a unique L. pennellii chromosome 7 marker band at CT113 which could be in the region of $I I$ (Fig. 5). To prove this, a genotype with $I I$ but not $I$ would need to be developed. Unfortunately, this was not done with the $\mathrm{F}_{2}$ from line 415 because the RFLP data were not available at the time the complementation test was conducted. Sarfatti et al. (1991) reported II was located between TG20 and TG128. According to the map of Tanksley et al. (1992), CT113 is $6.5 \mathrm{cM}$ distal to TG20 from TG128 and 25.8 to $29.5 \mathrm{cM}$ from $I-3$. Thus, our results vary somewhat from Sarfatti et al. (1991) as to the location of II. If line 415 does not have the $I 1$ gene near CT113 and the region reported by Sarfatti et al. (1991) was correct, other data in these experiments would reduce the possible location for the $I 1$ gene to a $2.4 \mathrm{cM}$ region between TG 20 and CT54 or a $3.6 \mathrm{cM}$ region between TG216 and TG639. Thus, $I I$ would be either $11.5-15.1 \mathrm{cM}$ or $17.5-19.9 \mathrm{cM}$ from $I-3$. It is clear that lines with resistance only to races 2 and 3 were obtained (Fig. 1) so $I I$ must exist and the likely locations have been mentioned. Accordingly, $I-3$ does not confer race 1 resistance as has been claimed (Sela-Buurlage et al. 2001).

A two-gene model was supported by the race 2 inoculation data for $\mathrm{F}_{2}$ populations derived from two lines resistant to both races 2 and 3 crossed with Fla. 7182 (I-2) (Table 2). This conclusion would indicate the lines with resistance to both races 2 and 3 have a resistance gene on chromosome 7 as is supported by the marker data (Figs. 4 and 5). The data also support dominant control of race 2 resistance by the gene on chromosome 7 .

RFLP ANALYSIS OF STEPPED ALIGNED INBRED RECOMBINANT LINES. The three lines resistant to race 2 alone all had L. pimpinellifolium alleles in the TG105 region indicating they have the $I-2$ gene (Ori

Fig 3. Overhead and side views of plants of line $73230 \mathrm{~d}$ after inoculation with races 1, 2, or 3 of fusarium wilt in Spring 2001. The black lines on the sidewalls are at $5 \mathrm{~cm}$ intervals. The outside row on the right in the race 1 pictures are controls with four plants of 'Bonny Best' $\left(I^{+}\right)$to the front and 'Manapal' $(I)$ toward the back.

\section{Line 732}

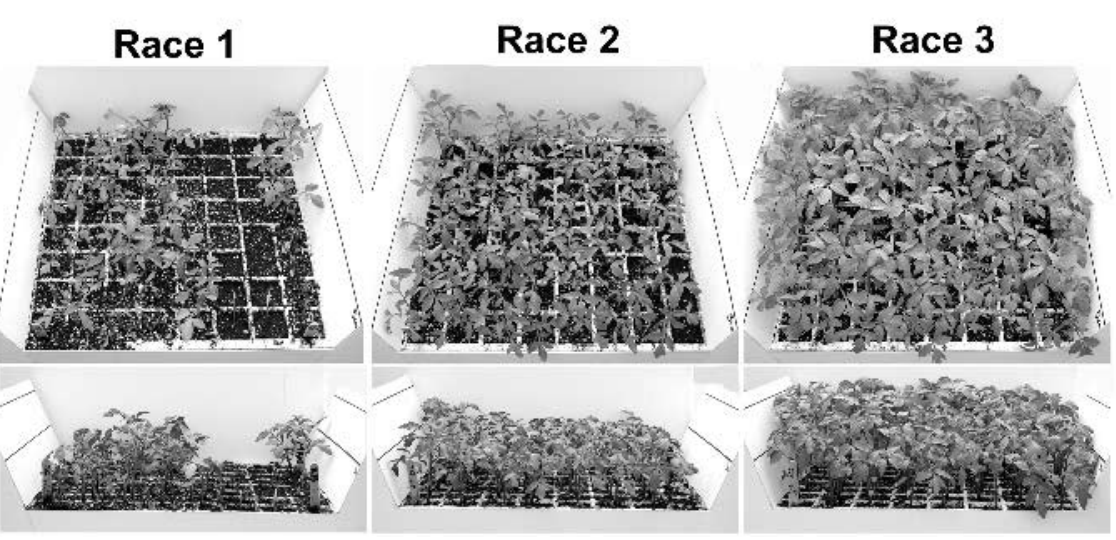


Table 1. Fusarium wilt race 1 disease incidence for three fusarium wilt race 1 resistant inbreds, their $\mathrm{F}_{2} \mathrm{~s}$ from crosses with 'Manapal' ( $I$ gene) and control lines.

\begin{tabular}{lccccc}
\hline Genotype & $\begin{array}{c}\text { Total } \\
\text { plants }\end{array}$ & $\begin{array}{c}\text { No. } \\
\text { healthy }\end{array}$ & $\begin{array}{c}\text { No. } \\
\text { diseased }^{z}\end{array}$ & \multicolumn{2}{c}{$\begin{array}{c}\text { Expected } \\
\text { ratio }^{y}\end{array}$} \\
\hline Experiment 1 & & & & & \\
$\chi^{2}$
\end{tabular}

${ }^{2}$ Number in parentheses is the percentage diseased plants.

yFor a two-gene model, $I$ on chromosome 11 from 'Manapal' and $I 1$ on chromosome 7.

et al, 1997; Sarfatti et al., 1989; Segal et al., 1992; Simon et al., 1998; Fig. 4). Thus, they are reciprocal recombinants with the race 1 alone lines. There is a considerable distance $(52.2 \mathrm{cM})$ between reported markers linked to $I$ (TG523) and $I$-2 (TG105). It is surprising that it has taken so long to show a clear linkage break between these genes. Tomato breeders incorporating $I-2$ into improved germplasm would typically be using recurrent parents possessing I. It is not known how much effort was put toward breaking the desirable linkage of the two resistances. This is the first report of lines with $I-2$ that are susceptible to race 1 . The reduction of race 1 susceptibility by $I-2$ reported by Laterrot and Philouze, (1984) was not apparent with our lines (Fig. 1).

By comparing the RFLP data from lines resistant to both races 2 and 3 (especially 218) with lines only resistant to race 3 (732 and 751), it is seen that the latter are missing $L$. pennellii alleles at markers TG183, TG174, and CT43 (Fig. 5). Sela-Buurlage et al. (2001) found $I-3$ was flanked by TG110 and TG183 thus placing TG110 on chromosome 7. However, previous RFLPmaps revealed that TG110 was located on chromosome 11 (Pillen et al. 1996; Sarfatti et al., 1989; Tanksley et al., 1992). Our race 3 resistant lines, 732 and 751, each had a crossover between TG170 and TG183 that resulted in a partial loss of resistance to race 2. From our data, crossovers separating the race 2 and race 3 resistance genes could be anywhere between TG170 and CT43, a distance of $10.2 \mathrm{cM}$. This distance can be reduced by considering the introgression line 20-1 data of Sela-Buurlage et al. (2001). Line 20-1 has a short $L$. pennellii segment containing $I-3$ flanked by TG110 on one side and TG217, TG170 and TG183 on the other. Line 20-1 was resistant to both races 2 and 3. Since 732 and 751 have lost their high level of race 2 resistance and they do not have the TG183 marker, it can be concluded that crossovers affecting race 2 resistance must be between TG170 and TG183, a distance of $2 \mathrm{cM}$.

It should be mentioned that Burbidge et al. (2001) present a different chromosome 7 map than that of Tanksley et al. (1992). Using the former map with our data left a L. esculentum gap between I-3

Fig. 4. Survey of 18 RFLP markers on chromosome 11 in 14 tomato lines with various resistances to fusarium wilt race 1,2 , and 3 . Resistance for each line is indicated next to line names above the line designation. Black bars represent chromosome segments of Lycopersicon pimpinellifolium genomic region. Map distances of RFLPs are indicated next to the markers as shown by Tanksley et al., (1992). Asterisks adjacent to the markers indicate the region of Fusarium resistance genes; where * and ** indicate the reported locations of the $I$ and $I-2$ genes, respectively.

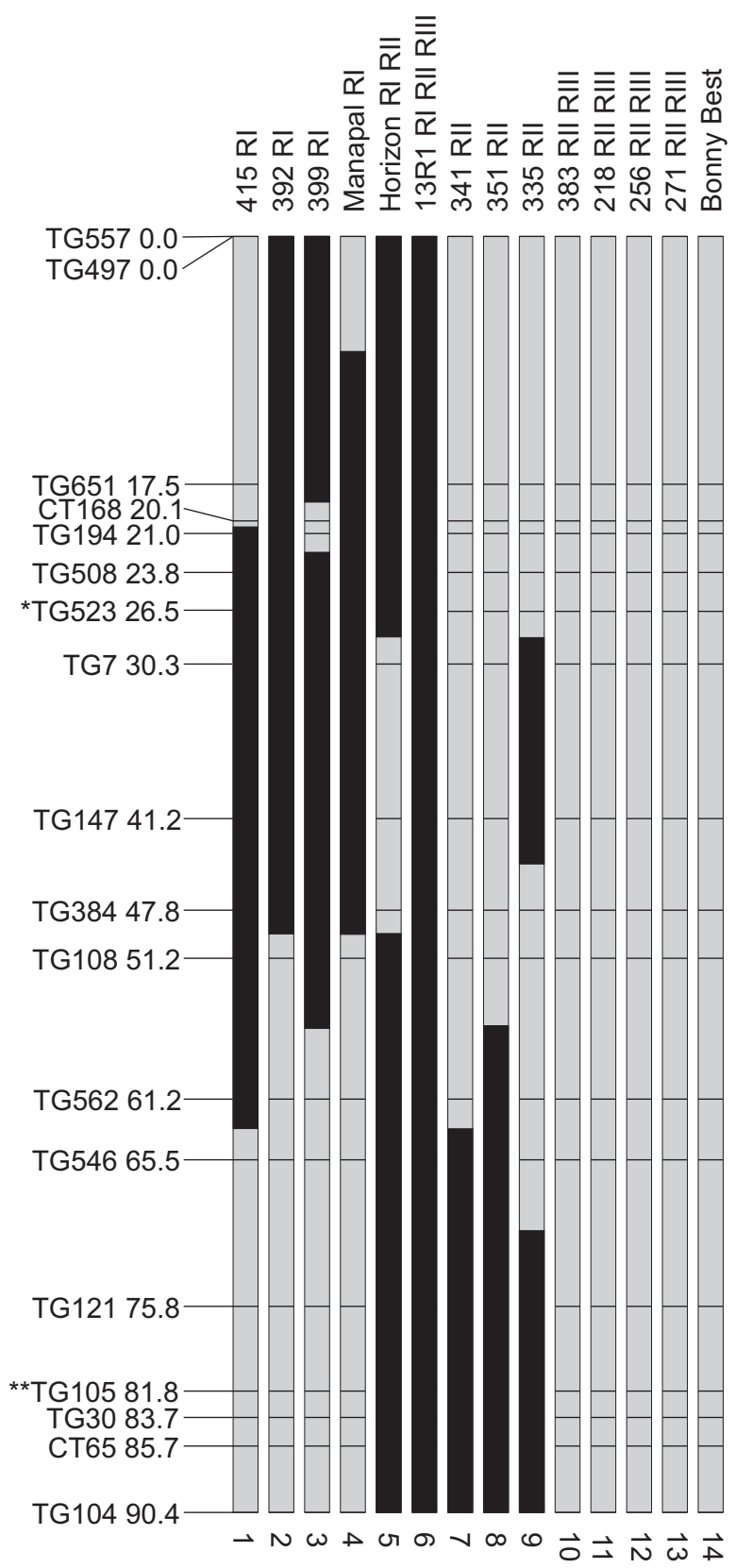




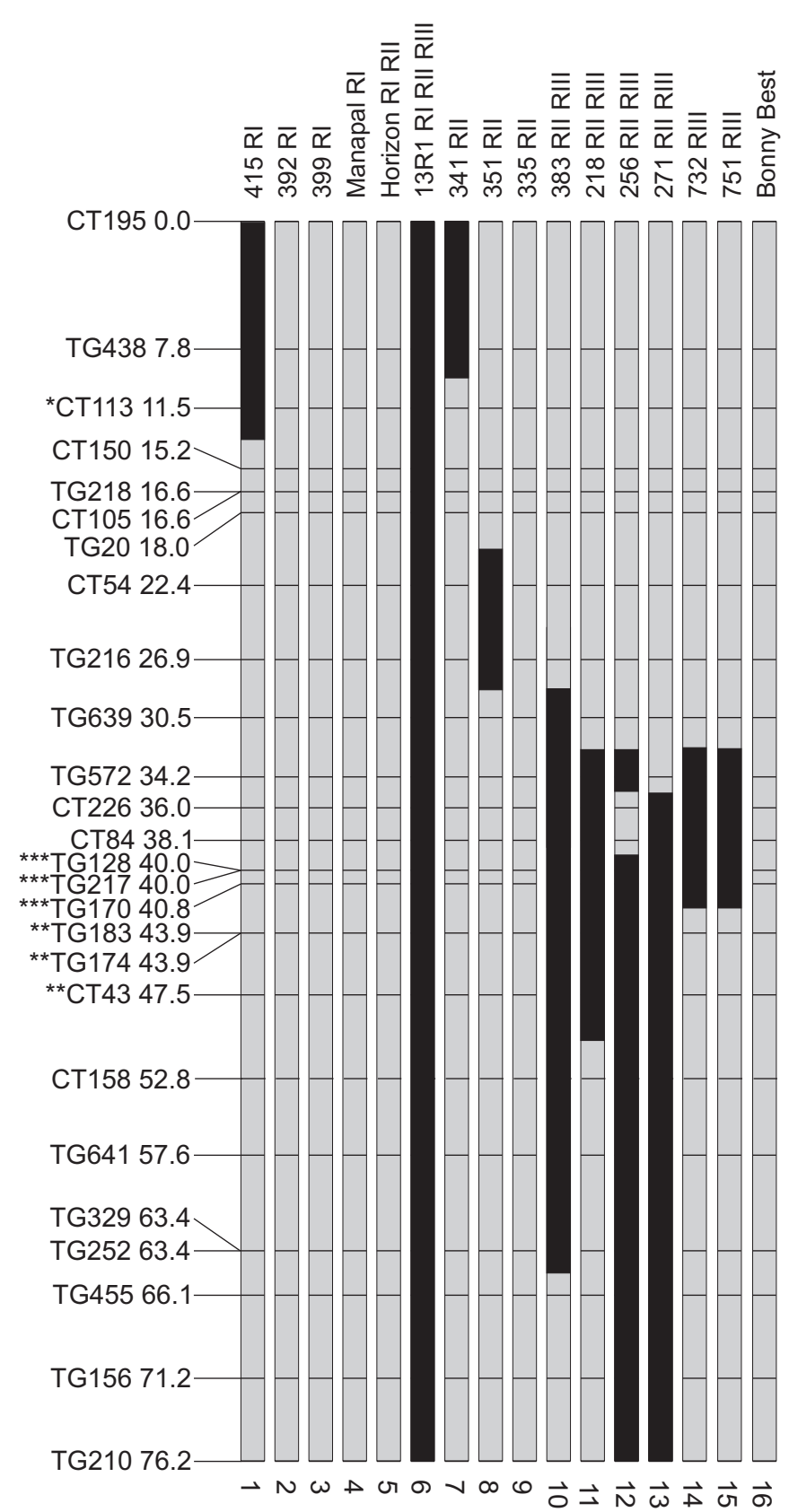

and the crossovers so the Tanksley et al. (1992) map provided the more likely marker order for our results.

However, it cannot be definitely concluded whether a gene other than $I-3$ is involved in the intermediate race 2 response. Sela-
Fig. 5. Survey of 26 RFLP markers on chromosome 7 in 16 tomato lines with various resistances to fusarium wilt race 1,2 , and 3 . Resistance for each line is indicated next to line names above the line designation. Black bars represent chromosome segments of Lycopersicon pennellii genomic region. Map distances of RFLPs were indicated next to the markers as shown by Tanksley et al., (1992). Asterisks adjacent to the markers indicate the region of fusarium resistance genes; where $*$ and $* *$ indicate proposed locations of the $I 1$ and a putative race 2 gene (see text), respectively and $* * *$ indicates the reported location of $I-3$. All lines resistant to races 2 and 3 alone, and race 3 alone, and I3R-1 had the L. pennellii Got-2 allele. All other lines had the L. esculentum Got-2 allele.

Buurlage et al. (2001) stated that $I-3$ conferred race 2 resistance as well as race 3 resistance. If this is true, then it is possible that the crossovers occurred within the $I-3$ locus, which might be a complex locus as has been reported for I-2 (Ori et al., 1997; Simons et al., 1998). The crossovers could have removed an area affecting race 2 but not race 3 resistance. Alternatively, I-3 could confer only race 3 resistance, while race 2 resistance is conferred by a gene tightly linked to $I-3$. The race 2 locus could be a complex locus and the crossovers could have occurred within that locus, thus causing the intermediate race 2 response. It could then be hypothesized that a crossover between the two loci would result in a recombinant line with clear resistance only to race 3 (and, reciprocally, to race 2). Such genotypes have not been recovered despite considerable effort. Thus, tomato breeders incorporating race 3 resistance into race 1 resistant recurrent parents would be likely to carry race 2 resistance without having to conduct race 2 inoculations.

Within an individual plant species, genes conferring resistance to different pathogens are often clustered in the same chromosome region (Gebhardt and Valkonen, 2001; Grube et al., 2000). Hulbert et al. (2001) suggested that the evolution of genes clustering is driven by selection on allelic variation created by mutation and reassorted by recombination between alleles and sometimes between different gene family members. Our results indicated fusarium wilt resistance genes are tightly clustered on chromosome 7 but more loosely clustered on chromosome 11.

\section{Summary}

Reciprocal recombinants with only race 2 or race 1 resistance on chromosome 11 were obtained. This report is the first of race 2 resistant lines without any race 1 resistance despite the fact that race 1 resistance was conferred by the $I$ gene located approximately $52.2 \mathrm{cM}$ from the $I-2$ gene. Further work is needed to determine the precise location of the $I$ gene which is between TG523 and TG7.

Four recombinant lines with resistance to only races 2 and 3 on chromosome 7 were obtained, but a reciprocal recombinant with only race 1 resistance due solely to a chromosome 7 gene was not. One line with race 1 resistance genes on both chromosome 11 and 7 may have been obtained, but further work is required to separate

Table 2. Fusarium wilt race 2 disease incidence for two inbreds resistant to races 2 and 3, their $\mathrm{F}_{2} \mathrm{~s}$ from crosses with Fla. 7182 (I-2 gene), and control lines.

\begin{tabular}{lccccc}
\hline Genotype & Total & No. & No. & \multicolumn{2}{c}{ Expected } \\
plants & healthy & diseased $^{z}$ & ratio $^{y}$ & $\chi^{2}$ \\
\hline 218 & 100 & 99 & $1(1.0)$ & $1: 0$ & --- \\
$(218 \times 7182) \mathrm{F}_{2}$ & 240 & 220 & $20(8.3)$ & $15: 1$ & 1.78 \\
256 & 105 & 103 & $2(1.9)$ & $1: 0$ & --- \\
$(256 \times 7182) \mathrm{F}_{2}$ & 480 & 455 & $25(5.2)$ & $15: 1$ & $0.1-0.5$ \\
Bonny Best & 120 & 1 & $119(99.1)$ & $0: 1$ & --- \\
Manapal & 80 & 4 & $76(95.0)$ & $0.1-0.5$ \\
Fla. 7182 & 126 & 125 & $1(0.8)$ & --- & -- \\
\end{tabular}

zNumber in parentheses is the percentage of diseased plants.

yFor a two-gene model, I-2 on chromosome 11 from Fla. 7182 and another gene on chromosome 7. 
the two genes and definitively prove that both genes are present in the line. The data indicate that the $I-3$ gene does not confer race 1 resistance and support the existence of a reported race 1 resistance gene $I 1$. The precise location of $I I$ requires further study. Two lines with resistance to race 3 and intermediate resistance to race 2 were obtained, but the reciprocal recombinant was not. Nor was there clear recombination between race 3 and race 2 resistance. A gene in a $2-c M$ region tightly linked to the $I-3$ gene between TG 170 and TG183 likely confers race 2 resistance.

\section{Literature Cited}

Agrama, H.A. and M.E. Moussa. 1996. Mapping QTLs in breeding for drought tolerance in maize (Zea mays L.). Euphytica 91:89-97.

Alexander, L.J. and C.M. Tucker. 1945. Physiological specialization in the tomato wilt fungus Fusarium oxysporum f. lycopersici. J. Agr. Res. 70: 303-313.

Alon, H., J. Katan, and N. Kedar. 1974. Factors affecting penetrance of resistance to Fusarium oxysporum $\mathrm{f}$. sp. lycopersici in tomatoes. Phytopathology 64:455-461.

Bohn, G.W. and C.M. Tucker. 1939. Immunity to fusarium wilt in the tomato. Science 89:603-604.

Bohorova, N., S. Fenell, S. McLean,A.Pellegrineschi, and D. Hoisington. 1999. Laboratory Protocols: CIMMYT Applied Genetic Engineering Laboratory. Mexico D.F., CIMMYT, México.

Bournival, B.L., J.W. Scott, and C.E. Vallejos. 1989. An isozyme marker for resistance to race 3 of Fusarium oxysporum f. sp. lycopersici in tomato. Theor. Appl. Genet. 78:489-494.

Bournival, B.L., C.E. Vallejos, and J.W. Scott. 1990. Genetic analysis of resistances to races 1 and 2 of Fusarium oxysporum f. sp. lycopersici from the wild tomato Lycopersicon pennellii. Theor. Appl. Genet. 79:641-645.

Burbidge, A., T.M. Grieve, K.J. Woodman, and I.B. Taylor. 1995. Strategies for targeted transposon tagging of ABA biosynthetic mutants in tomato. Theor. Appl. Genet. 91:1022-1031.

Chunwongse, J., T.B. Bunn, C. Crossman, J. Jiang, and S.D. Tanksley. 1994. Chromosomal localization and molecular marker tagging of the powdery mildew resistance gene $(L v)$ in tomato. Theor. Appl. Genet. 89:76-79.

Cirulli, M. and L.J. Alexander. 1966. A comparison of pathogenic isolates of Fusarium oxysporum f. lycopersici and different sources of resistance in tomato. Phytopathology 56:1301-1304.

Doganlar, S., J. Dodson, B. Gabor, T. Beck-Bunn, C. Crossman, and S.D. Tanksley. 1998. Molecular mapping of the $p y-1$ gene for resistance to corky root rot (Pyrenochaeta lycopersici) in tomato. Theor. Appl. Genet. 97:784-788.

Fulton, T.M., J.C. Nelson, and S.D. Tanksley. 1997. Introgression and DNA marker analysis of Lycopersicon peruvianum, a wild relative of the cultivated tomato, into Lycopersicon esculentum, followed through three successive backcross generations. Theor. Appl. Genet. 95:895-902.

Gebhardt, C. and J.P. Valkonen. 2001. Organization of genes controlling disease resistance in the potato genome. Annu. Rev. Phytopathol. 39:79-102.

Grattidge, R. and R.G. O'Brien. 1982. Occurrence of a third race of fusarium wilt of tomatoes in Queensland. Plant Dis. 66:165-166.

Grube, R.C., E.R. Radwanski, and M. Jahn. 2000. Comparative genetics of disease resistance within the Solanaceae. Genetics 155:873-887.

Haanstra, J.P.W., C. Wye, H. Verbakel, F. Meijer-Dekens, P. van den Berg, P. Odinot, A.W. van Heusden, S. Tanksley, P. Lindhout, and J. Peleman. 1999. An integrated high-density RFLP-AFLP map of tomato based on two Lycopersicon esculentum $\times$ L. pennellii $\mathrm{F}_{2}$ populations. Theor. Appl. Genet. 99:254-271.

Hulbert, S.H., C.A. Webb, S.M. Smith, and Q. Sun. 2001. Resistance gene complexes: Evolution and utilization. Annu. Rev. Phytopathol. 39:285-312.

Kaloshian, I., J. Yaghoobi, T. Liharska, J. Hontelez, D. Hanson, P. Hogan, T. Jesse, J. Wijbrandi, G. Simons, P. Vos, P. Zabel, and V.W. Williamson. 1998. Genetic and physical localization of the root-knot nematode resistance locus $M i$ in tomato. Mol. Gen. Genet. 257:376-385.

Kearsey, M.J. 2002. QTLanalysis: problems and (possible) solutions, p. 45-49. In: M.S. Kang (ed.). Quantitative genetics, genomics and plant breeding. CABI Publ., Oxon, U.K.

Laterrot, H. 1976. Localisation chromosomique de 2 chez la tomate controlant la resistance au pathotype 2 de Fusarium oxysporum f. lycopersici. Ann. Amel. Plant. 26:485-491.

Laterrot, H. and J. Philouze. 1984. Recombination between pathotype 1 (I-2 allele) and susceptibility to pathotype 0 (I+ allele) of Fusarium oxysporum f. sp. lycopersici in tomato (Lycopersicon esculentum Mill.), p. 70-74. In: Pays-Bas (ed.). Proc. Meeting of the Eucarpia Tomato Working Group. May 1984. Wageningen, The Netherlands.

Lindhout, P. 1995. Mapping disease resistance genes in tomato: a toy for the geneticist or a joy for the breeder? Acta Hort. 412:39-48.

Martin, G.B., S.H. Brommonschenkel, J. Chunwongse, A. Frary, and M.W. Ganal. 1993. Map-based cloning of protein kinase gene conferring disease resistance in tomato. Science 262:1432-1436.

McGrath, D.J., D. Gillespie, and L. Vawdrey. 1987. Inheritance of resistance to Fusarium oxysporum f. sp. lycopersici races 2 and 3 in Lycopersicon pennellii. Aust. J. Agric. Res. 38:729-733.

Ori, N., Y. Eshed, I. Paran, G. Presting, D. Aviv, S. Tanklsey, D. Zamir, and R. Fluhr. 1997. The $I 2 C$ family from the wilt disease resistance locus $I 2$ belongs to the nucleotide binding, leucine-rich repeat superfamily of plant resistance genes. Plant Cell 9:521-532.

Paddock, E.F. 1950. A tentative assignment of Fusarium-immunity locus to linkage group 5 in tomato. Genetics 35:683-684.

Pillen, K., O. Pineda, C.B. Lewis, and S.D. Tanksley. 1996. Status of genome mapping tools in the taxon Solonaceae, p. 281-308. In: A. H. Paterson (ed.). Genome mapping in plants. Academic Press, Inc., San Diego, Calif.

Ron, M., R. Kantety, G.B. Martin, N. Avidan, Y. Eshed, D. Zamir, and A. Avni. 2000. High-resolution linkage analysis and physical characterization of the EIX-responding locus in tomato. Theor. Appl. Genet. 100:184-189.

Sarfatti, M., M. Abu-Abied, J. Katan, and D. Zamir. 1991. RFLP mapping of I1, a new locus in tomato conferring resistance against $F$ usarium oxysporum f. sp. lycopersici race 1. Theor. Appl. Genet. 82:22-26.

Sarfatti, M., J. Katan, R. Fluhr, and D. Zamir. 1989. An RFLP marker in tomato linked to the Fusarium oxysporum resistance gene I2. Theor. Appl. Genet. 78:755-759.

Scott, J.W. and J.P. Jones. 1989. Monogenic resistance in tomato to Fusarium oxysporum f. sp. lycopersici race 3. Euphytica 40:49-53.

Scott, J.W. and J.P. Jones. 1990. Soil-borne fungal resistance in Lycopersicon pennellii accessions. HortScience 25:1068 (abstr.).

Segal, G., M. Sarfatti, M.A. Schaeffer, N. Ori, D. Zamir, and R. Fluhr. 1992. Correlation of genetics and physical structure in the region surrounding the I2 Fusarium oxysporum locus in tomato. Mol. Gen. Genet. 231:179-185.

Sela-Buurlage, M.B., O. Budai-Hadrian, Q. Pan, L. Carme-Goren, R. Vunsch, D. Zamir, and R. Fluhr. 2001. Genome-wide dissection of Fusarium resistance in tomato reveals multiple complex loci. Mol. Genet. Genomics 265: 1104-1111.

Simons, G., Groenendijk, J. Wijbrandi, M. Reijans, J. Groenen, P. Diergaarde, T. van der Lee, M. Bleeker, J. Onstenk, M. de Both, M. Haring, J. Mes, B. Cornelissen, M. Zabeau, and P. Vos. 1998. Dissection of the Fusarium $I 2$ gene cluster in tomato reveals six homologs and one active gene copy. Plant Cell 10:1055-1068.

Stall R.E. and J.W. Walter. 1965. Selection and inheritance of resistance in tomato to isolates of races 1 and 2 of the fusarium wilt organism. Phytopathology 55:1213-1215.

Stamova B.S. and R.T. Chetelat. 2000. Inheritance and mapping of cucumber mosaic virus resistance introgressed from Lycopersicon chilense into tomato. Theor. Appl. Genet. 101:527-537.

Tanksley, S.D., M.W. Ganal, J.P. Prince, M.C. de Vincente, M.W. Bonierbale, P. Broun, T.M. Fulton, J.J. Giovannoni, S. Grandillo, G.B. Martin, R. Messeguer, J.C. Miller, L. Miller, A.H. Paterson, O. Pineda, M.S. Roder, R.A. Wing, W. Wu, and N.D. Young. 1992. High-density molecular linkage maps of the tomato and potato genomes. Genetics 132:1141-1160.

Vallejos, C.E. 1983. Enzyme activity staining, p. 469-516. In: S.D. Tanksley and T.J. Orton (eds.). Isozymes in plant genetics and breeding. vol. 1A. Elsevier, Amsterdam.

Young, N.D., D. Zamir, M.W. Ganal, and Tanksley. 1988. Use of isogenic lines and simultaneous probing to identify DNA markers tightly linked to the Tm-2a gene in tomato. Genetics 120:579-585.

Zamir, D., M.I. Ekstein, Y. Zagay, N. Navot, and M. Zeiban. 1994. Mapping and introgression of tomato yellow leaf curl virus tolerance gene, $T y-1$. Theor Appl. Genet. 88:141-146. 